\title{
Symbolická vymístění, národní identita a (re)konstrukce paměti
}

\author{
Václav Štětka
}

Motto:

„Historie českého národa, a do určité míry každého národa, je historií přepisování své vlastní historie.“

(Ladislav Holý: Malý český člověk a skvělý český národ, 2001: 107)

Tento esej nastiňuje některé možnosti aplikace konceptu „,vymístěni““ (displacement) na teorii konstrukce a symbolické reprezentace národní identity. ${ }^{1}$ Jeho vstupním předpokladem je teze, že mechanismus „,vymístění“, chápaný šířeji než jako pouhá fyzická dislokace, ${ }^{2}$ sehrává v procesu konstrukce jakékoli kolektivní - tedy i národní - identity klíčovou roli. Vysvětlení této role se nachází již v samotném termínu. Pojem identita má základ v latinském kořeni „idem“, což znamená „stejný“. Tato stejnost je ovšem zároveň růzností, nebot’ bez porovnání s odlišným ztrácí pojem totožnosti smysl. Veškeré identity, a obzvláště kulturní, se konstituují jako diference v rámci určitého systému, v rámci vymezování se vůči jiným (Morley, Robins 1995: 45). Richard Jenkins, s odkazem na George Simmela - jednoho z prvních sociologů, kteří tuto dualitu systematicky rozpracovávali - uvádí, že identita je tvořena dvěma dynamickými principy, které se navzájem předpokládají a doplňují: „Pojem identity simultánně ustavuje dva možné vztahy porovnání mezi věcmi nebo osobami: similaritu na jedné straně a diferenci na straně druhé“ (Jenkins 1996: 4). Důležitou, ba fundamentální úlohu zde hraje koncept hranice, na které se veškeré kolektivní identity utvářejí (Jenkins 1996: 112). Na této (imaginární) hranici se odehrává „interní - externí dialektika kolektivní identifikace“: jednak se člověk skrze definiční znaky jisté skupiny vymezuje jako její člen, současně rozpoznává jisté distinktivní znaky, které jej odlišují od členů jiného společenství.

Skupinová identifikace jakožto negativní sebevymezení vůči ne-členům dané komunity dává ve vědomí individua vzniknout symbolické antinomii, subjektivně zakoušené jako MY a ONI. ${ }^{3}$ Tato binární opozice je zejména ze strukturalistických pozic vysvětlována jako antropologická konstanta, základní lidská vlastnost, pomocí níž člověk strukturuje svět, který obývá, a dokáže se v něm orientovat. „Obraz sebe sama a obraz cizího [...] jsou kontrární pojmové dvojice, které členi prostor naší zkušenosti a umožňují jednat“ (Loewenstein 1997: 67).

\section{Národ jako soubor symbolických reprezentací}

Národní identita jako specifická forma kolektivní identity se těmto zákonitostem nevymyká. Národ sám, coby suverénní, avšak limitovaná imaginární komunita (Anderson 1991: 7), potřebuje ke svému vymezení okolní národy či etnika, jež představují to, čím není. Tato distinkce, a tedy současně národní identita, je objektivizována prostřednictvím rozsáhlého arzenálu identifikátorů (Střítecký 1994)4 - zejména symbolů, mýtů a rituálů, jež zajišt’ují exkluzivitu dotyčného národa ve společenství ostatních, cizích národů. ${ }^{5}$ 
Podle Karen Cerulo fungují národní symboly jako moderní totemy: spojují mytickou, posvátnou substanci národa se specifickou, manifestní formou, která je zakotvena v každodenně zakoušeném obrazu, zvuku nebo doteku (Cerulo 1995: 4). Není to jen metafora, protože jejich historické kořeny leží právě v totemických symbolech primitivních kmenů a klanů. Jejich hlavní funkce - rozlišovat, kdo k danému kmeni či klanu patří a kdo ne - se po tisíciletí nezměnila; co ovšem doznalo proměny, byla vlastnická práva, která na ně byla uplatňována. Zatímco totem byl personifikací klanu a jako takový také celému klanu náležel, královské rodiny a vladařské dynastie starověku a středověku totemické symboly zprivatizovaly. Nástup moderních národů, představovaných jako „horizontální bratrství“ (Anderson 1991), ovšem posunuje vývoj totemických reprezentací do nové fáze: národní symboly znamenají úspěšnou kombinaci lidového charakteru kmenových totemů s elitářstvím starověkých a středověkých emblémů. V tomto smyslu národní symboly redemokratizovaly kolektivní symboliku: nejsou výhradním majetkem vladařů a elit, ale náležejí - tedy alespoň proklamativně - „Všemu lidu“ (Cerulo 1995: 13).

Národní symboly a mýty se pohybují ve specifické semiosféře - sémiotickém světě plném referencí k národní minulosti, přítomnosti i budoucnosti; ve světě, který člověka ze všech stran obklopuje a v němž je také generováno jisté kanonické a morálně závazné pojetí národní identity. ${ }^{6}$ Jakkoli je tato semiosféra sama o sobě polem či sítí významů - abstraktním, imaginárním prostorem, který sdílejí všichni, jichž se výzvy k nacionálnímu uvědomění nějak dotýkají -, je nicméně zakotvena nad určitým konkrétním teritoriem v bodech, místech a materiálních objektech, jež lze spolehlivě lokalizovat. Takové teritorium se nazývá v nacionalistickém diskurzu vlastí či domovinou (homeland, Vaterland) a místa, jež obklopuje zvláštní aura historicko-nacionálních významů, formují její symbolickou topografii (Smith 1991). V procesu této symbolické konstrukce reality, kdy se z určitého území (land) stává domovina (homeland) a z určité krajiny (landscape) etnokrajina (ethnoscape), ${ }^{7}$ hraje významnou úlohu národní inteligence. Básníci, hudebníci, malíři, sochaři, spisovatelé, historici a archeologové, dramatici, filologové, antropologové a folkloristé fungují jako tvưrci a následně strážci těchto „morálních map“, jež zásobují národ seznamem míst, „kde ,naši“ mudrci, svatí a hrdinové žili, pracovali, modlili se a bojovali. To vše činí domovinu unikátní. Její řeky, pobřeží, jezera, hory a města se stávají ,posvátnými “ - místy uctívání a velebení, jejichž vnitřní význam může být pochopen jedině zasvěcenými, tedy uvědomělými členy národa“"(Smith 1991: 9).

\section{Identita a obrazy minulosti}

Zatímco národní semiosféra má kumulativní charakter - shromažd’ují se v ní veškeré znaky, symboly a mýty, které kdy byly spojovány s konceptem daného národa, bez ohledu na jejich vzájemné rozpory - konkrétní podoba symbolického aparátu, jímž je udržována kanonická verze národní identity, závisí na tom, jaká verze interpretace národní historie ve společnosti právě převládá. Jak píše Ladislav Holý, „historie [...] není jednoduše cokoli, co se stalo v minulosti nebo co z této minulosti bylo zaznamenáno. Z množství minulých událostí jsou zaznamenány (a tudíž uchovány v paměti) jen ty, které se považují za důležité. [...] Historie je tedy konstruována z výběru událostí chaotické minulosti, o kterých se domníváme, že mají historický význam pro současnost; jsme to, co jsme (nebo kdo jsme), protože to či ono se stalo v naší minu- 
losti“ (Holý 2001: 106). Dochází tedy k redukci komplexity sociálního systému, kterou je sice možno spolu s Niklasem Luhmannem chápat jako funkcionální nezbytnost, ale na které je z hlediska sociologie vědění (respektive, jak navrhuje Miloš Havelka [2001], sociologie historiografie), zajímavé právě to, jaké události se do historiografického přehledu dostanou a jaké nikoli, respektive, jakým způsobem dochází ke „konstrukci sakralizovaného rámce sociální souvislosti smyslu, to znamená [...] specifického výkladu skutečnosti, který má silně sociálně-integrativní funkce, a zároveň [...] specifického ospravedlňování jednotlivých sociálních institucí a jednotlivých politických rozhodnuti'“ (Havelka 2001: 12). Historie (jako nástupkyně mýtu) má důležitou roli v legitimizaci sociálního řádu; z toho nutně vyplývá, že se její výklad stává v rámci určité společnosti předmětem mocenského soupeření. Loewenstein (1997) hovoří v této souvislosti o „hře zvané ,ovládnutí pole historie“ “. Podklady pro tuto metaforu skýtají zejména mocensko-politické zvraty v rámci jedné společnosti (národa), po nichž zpravidla následuje přepisování historických knih a učebnic, přičemž ,některá fakta a lidé zmizí, jiní jsou vyzdviženi; některé události jsou interpretovány novým způsobem“ (Mach 1989: 61). ${ }^{8}$ V návaznosti na reinterpretaci národní historie tedy dochází $\mathrm{v}$ takových situacích pravidelně $\mathrm{k}$ rekonstrukci galerie národních symbolů a přepisování či doplňování symbolické topografie národa.

A je to právě tento moment, ve kterém lze identifikovat působení mechanismu vymístění (displacement). Jak již bylo v úvodu naznačeno, chápeme jej primárně jako diskurzivní praktiku, která se realizuje $\mathrm{v}$ symbolických strukturách. Tento prŕstup fyzickou dislokaci nevylučuje, ale pracuje s ní jako s komplementární strategií, která může, ale nezbytně nemusí, symbolické vymístění doprovázet. Ani otázka časové posloupnosti není jednoznačně zodpověditelná; symbolické vymístění může fyzickému předcházet (jako v př́ípadě Židů v nacistickém Německu), odehrávat se současně (jako v př́ípadě tzv. divokého odsunu Němců ze Sudet těsně po skončení druhé světové války), anebo jej může - v různém časovém intervalu - následovat (jako v př́ípadě politických čistek v gottwaldovském Československu). V každém případě je hlavním smyslem symbolického vymístění v rámci národa demonstrativní očištění národní pospolitosti, očištění od cizích, poskvrňujících elementů, od „falešných“ historiografických interpretací. Stručně řečeno, jde o proklamativní nalézání „pravdivého a autentického obrazu národa“, jenž byl v důsledku neblahých historických okolností či záludných neprátelských konspirací překryt nánosy bludných faktů a výkladů, znemožňujících vidět jeho pravý charakter a dějinné poslání. Tento postup má opět archaické kořeny. „Jako při kultické oběti neběží o skutečnou vinu, nýbrž o ochranný obřad, o rituál, který má vytvářet jednomyslnost, vypudit násilí z pospolitosti a obnovit její původní čistotu“, píše Loewenstein (1997: 119), „tak i v ,moderním‘ fundamentalismu [za nějž Loewenstein nacionalismus potenciálně považuje - pozn. VŠ] dochází k reaktivaci jazykově sotva vyjádřitelných afektů, prascén, kolektivních iluzí a vylučovacích rituálů; cílem je uspat každou individuální odpovědnost a znemožnit zpracování nových zkušeností." Podstatné nicméně je, že se toto vyloučení téměř nikdy nepodaří provést úplně; nepohodlné znaky a symboly jsou vymístěny z národního panteonu, ale zůstávají součástí národní semiosféry, přinejmenším do té doby, než je zničen poslední záznam o jejich existenci a zemře poslední člověk, který si na ně pamatuje. ${ }^{9}$ Proto také ,„[...] to, co bylo vymístěno - rozptýleno, odloženo, potlačeno, odsunuto - je stále významně př́tomno: vymistěné, ale nikoli nahrazené, zůstává zdrojem problémů, pohyblivým podkladem označování, díky němuž se význam chvěje“ (Bammer 1994: xiii). ${ }^{10}$ 
V následující části se pokusíme ilustrovat toto symbolické vymístování na příkladech sporů o interpretaci české historie ve 20. století a proměn její oficiální verze, doprovázených proměnami národních identifikátorů, $v$ návaznosti na hlavní změny politického režimu. Během této krátké procházky dějinně-symbolickými zvraty bude věnována pozornost zejména barvitým osudům některých soch a pomníků, ale i veřejných prostranství - ulic a náměstí.

\section{Pomníkové vymísfování jako „úklid v dějinách“}

Tajemství a síla pomníků spočívá v tom, že jsou „na prvním místě symbolem, pak teprve artefaktem“; etablují se v nich „noví hrdinové nacionálních společností, jejichž sestava vypovídá o kolektivním historickém vědomí jako málokterý jiný pramen,“ píší Zdeněk Hojda a Jiří Pokorný v knize Pomníky a zapomníky (1996), o níž se následující část textu ze značné části opírá (přičemž se pokouší rozvést a doplnit sociologickou dimenzi této problematiky, které se dotyční autoři věnují spíše okrajově). Podle autorů je ,... likvidace pomníků [...] pro historika stejně legitimním projevem živého vztahování se k minulosti jako jejich vytváření. ,Živý provoz pomníku jako místa uctívání nebo hanobení je symptomem ,pomníkovosti‘. Teprve socha, o kterou nemá nikdo zájem ani v pozitivním, ani v negativním smyslu, přestává být pomníkem a stává se ,zapomníkem‘, mrtvým totemem“ (Hojda a Pokorný 1996: 20). Pomníky mají specifické místo v souboru národních symbolů i proto, že se jedná o symboly vysoce komplexní: jejich „životní dráha“, od počáteční ideje přes výstavbu až po eventuální odklizení (a př́padné opakování tohoto cyklu) je spojena s dalšími symbolickými akty, sloužícími k definování a prezentaci národní identity."

Vznik pomníkové horečky a uživání pomníků jako orientačních bodů je podle autorů vedle praktické potřeby orientace $\mathrm{v}$ prostoru, spojené s růstem měst $\mathrm{v} 19$. století, také psychologickou reakcí na ztrátu náboženských jistot, materializovaných v podobě kř̌̌žkủ, Božích muk, kapliček a kostelů. „Budování pomníků bylo přímým důsledkem sekularizace této společnosti - dříve by na jejich místě vznikl mariánský sloup či socha světce“ (Hojda a Pokorný 1996: 16). Jak autoři konstatují, pomníkový kult měl s úctou, která byla prokazována sochám svatých, mnoho společného, což se projevovalo jak využitím náboženské sémantiky v motivech pomníků, tak tím, že tyto se stávaly často novými poutními místy a jejich bezprostřední okolí novodobými posvátnými okrsky.

Jak již bylo řečeno, z hlediska sledování výstavby a transformace národní identity jsou nejzajímavější „pomníkové spory“; jsou obvykle spolehlivým indikátorem významných sociálně-politických změn uvnitř určité společnosti. Metaforicky tento proces popisuje Petr Pithart ve svém eseji „Neklidný život pražských pomníků a soch“ (1990): „Čas od času lidé uklízejí ve svých dějinách jako v dětském pokoji: vystaví jednu pannu a druhou hodí na dno skříně. Zdá se, že když několikrát uklidí, bude už konečně klid a pořádek. V české hlavě však pořádek není a spory o pomníky mohou kdykoli vypuknout s novou, prudkou silou. Jsou to totiž spory o identitu - o to, kdo jsme, odkud a kam jdeme“, píše Pithart (1990: 255-256). Pro účely této statě jsme zvolili spory o tři tradice, jež měly v různých dobách pro český národ orientační i legitimizační funkci, a jež byly, kromě jiného, reprezentovány prostřednictvím pomníků: tradici katolickou, habsbursko-německou a „masarykovskou“.

Jedním z nejznámějších případů „úklidu v dějinách“ a zároveň svědectvím boje za vymazání katolických reliktů z charakteru české národní identity vznikajícího československého státu je př́ípad Mariánského sloupu na Staroměstském náměstí. Byl postaven v roce 1650 
z rozhodnutí císaře Ferdinanda III. na pamět' uhájení Prahy před Švédy. Třetího listopadu 1918, tedy krátce po vyhlášení samostatnosti Československa, se skupina rozkurážených „vlastenců“, vracejících se právě z jakési národní slavnosti a vedených žižkovským bohémem Frantou Sauerem (hospodským kumpánem Jaroslava Haška), rozhodla vykonat na něm symbolickou pomstu za všechna příkoří, spáchaná na českém národě katolickou církví. Sloup byl zčistajasna re-sémantizován na symbol porážky na Bílé Hoře a jako takový nemilosrdně povalen a zlikvidován. ${ }^{12}$ Historie mariánského sloupu tím nicméně zdaleka neskončila. Pithart popisuje „kuriózní způsob, jakým byl sloup před několika lety [tj. v osmdesátých letech pozn. VŠ] při rekonstrukci náměstí připomenut. Byl totiž postaven svého druhu pomník - stínu, nota bene neexistujícímu stínu. Totiž stínu onoho sloupu.“ Jedná se o ,pražský poledník“, podle kterého Pražané poznávali poledne: to nastávalo, když se čáry v dlažbě dotkl stín mariánského sloupu (Pithart 1990: 264). Devadesátá léta přinesla rehabilitaci české katolické tradice a další kolo boje o ovládnutí symbolického prostoru, jakým Staroměstské náměstí bezpochyby je. V roce 1990 vzniká - pod ideovou záštitou propagace ekumenické tolerance - Společnost pro obnovu mariánského sloupu, která iniciovala položení nového základního kamene ve výroční den zničení sloupu, 3. 11. 1993, přesně na místo, kde originál původně stál. Posvěcený základní kámen se čtyřjazyčným textem „Zde stál a opět bude stát Mariánský sloup“ se stal ,během několika dnů předmětem vandalského činu, při němž neznámá osoba, možná na pokyn některého činovníka pražského magistrátu, špicí a kladivem zničila část nápisu, " píše pan Peroutka z dotyčné společnosti ${ }^{13}$ a dokumentuje tak fakt, že ona rehabilitace katolictví jako integrální součásti české národní identity není zdaleka obecně přijímána. ${ }^{14}$

V počátcích první republiky se boj o charakter české národní identity nesoustředil jen na odstřižení od katolické tradice, ale také od tradice habsbursko-rakouské (tvořící nicméně s katolicismem nerozlučnou dvojici) a pochopitelně od „němectvi“ jako takového. S tím souvisely i další symbolické útoky, zaměřené tentokráte na pomníky Habsburků, představitelů nenáviděného císařského režimu, ${ }^{15}$ ale i postav, jejichž jediným proviněním bylo to, že byli identifikováni jako Němci. Z řad panovnické dynastie byly v průběhu prvních let po vyhlášení republiky odstraněny např́klad sochy císaře Františka I. v Praze, ${ }^{16}$ Marie Terezie v Bratislavě ${ }^{17}$ a císaře Josefa II. v celé řadě zejména př́hraničních měst. ${ }^{18}$ Ještě před tím, už v roce 1918, byl z Malostranského náměstí odstraněn pomník maršála Radeckého, po celou předchozí dobu považovaného za „otce vojákư“ a ,jednoho z nejušlechtilejších synů české země“،, jak se o něm vyjádřil hrabě Nostitz při odhalení pomníku v roce 1858 (Hojda a Pokorný 1996: 50). Byl to ovšem ,symbol české loajality k říši, loajality, o níž Češi nechtěli už o padesát let později ani slyšet" (Pithart 1990: 260). ${ }^{19}$

Ikonoklastická vlna očisty od „Habsburko̊ a jejich pomahačů“, tj. především Němců, se nevyhnula ani zdánlivě zcela apolitickým, kulturním osobnostem. Vedle Schillerových soch byly terčem útoku především pomníky J. W. Goetha; a ještě před válkou stačil upadnout v nemilost dokonce i Mozart. O vybudování jeho sochy u Stavovského divadla žádal roku 1913 jeden německý spolek pražskou městskou radu. Tato žádost vzbudila ostrý nesouhlas řady tehdejších představitelů politického i společenského života a byla v zájmu ,zachování českosti Prahy“ zamítnuta. Mozart byl pro ně „zkrátka Němec, který s Čechami neměl nic společného, a proto není důvod budovat mu pomníky. Není také důvod vyhovět žádosti Němců, kteří by ho jistě využili k propagandistickým a demonstrativním a protičeským účelům“ (Hojda a Pokorný 1996: 127-133).20 
Změna politického režimu i vládnoucí ideologie po vzniku protektorátu Čechy a Morava 15. 3. 1939 si vynutila i změnu symbolického aparátu, jejíž součástí nutně bylo vymíst’ování některých nepohodlných součástí aparátu starého; v tomto př́ípadě zejména symbolů spojených se vznikem ČSR. Hlavním terčem „,pozornosti“ se staly pochopitelně pomníky T. G. Masaryka, jež po vzniku protektorátu často sloužily k demonstraci odporu vůči nacistické moci. Ta je ničila často $s$ úmyslem zabránit národnostním střetům s německým obyvatelstvem, pobouřeným skutečností, že Češi nepřestávali ani za okupace klást květiny k pomníku člověka, jehož K. H. Frank označil za jednoho z úhlavních nepřátel Německa (Hojda a Pokorný 1996: 199-200). Příznačné v této souvislosti je, že odstranění největšího z pomníků, deset metrů vysoké Masarykovy sochy v průčelí Jeskyně blanických rytírů u Rudky na Blanensku, ${ }^{21}$ se nezdařilo úplně: zůstaly z ní totiž obrovské boty, „svérázný kamenný znak dlouholeté oficiální nepř́ítomnosti T. G. Masaryka v českých dějinách“ (Macura 1993: 52).

Po válce byly pomníky TGM, pokud nebyly zničeny, nakrátko opět vyvezeny ze skladišt' a depozitářů; další vlna jejich likvidace po nástupu komunismu však nepřišla hned, nýbrž s malým zpožděním (došlo k ní až od počátku 50. let), daným určitým ambivalentním vztahem, který měli komunisté před Únorem a krátce po něm k osobě TGM; vztahem, který nebyl prostý jisté úcty. ${ }^{22}$ Rok 1968 znamenal další bod obratu ve veřejné prezentaci vztahů k Masarykovi: tehdy došlo k několika pokusům Masarykovy pomníky opět obnovit. Srpnové události tomu zabránily; poslední, čtvrtá etapa odhalování pomníků se tudíž uskutečnila až po listopadu 1989. Vyvrcholila v březnu 2000, kdy byla za přítomnosti velvyslankyně USA odhalena socha TGM v Praze na Masarykově nábřeží (Hojda a Pokorný 1996: 203).

\section{Prítomnost minulosti}

Z hlediska teorie symbolického vymístění je podstatný fakt, že po jakémkoli fyzickém odstranění pomníku/symbolu na jeho místě přetrvává - přinejmenším po určitou dobu - onen význam, který s ním byl po dobu jeho existence spojován. Podle V. Macury odstranění pomníku přináší „minusový efekt“ („minus-prijom“v teorii J. M. Lotmana, který tímto termínem popisoval stav, kdy náhlá nepř́itomnost něčeho vyvolává nutkavé očekávání přítomnosti něčeho jiného), jenž způsobuje, že prázdné místo, které po něm zbude, „není a hned tak nebude doopravdy prázdným místem. Cokoli se tu do tohoto jen zdánlivě volného prostoru umístí, vstoupí okamžitě do významového vztahu k monumentu, který tu krátce pobýval“" (Macura 1993: 56). Macura tuto teorii konkretizuje na př́kladu demolice gigantického letenského sousoší v čele s J. V. Stalinem - figurou, jež byla v padesátých letech oficiálně prezentována jako nejvyšší identifikační vzor pro celý národ. Rozhodnutí o odstranění pomníku padlo v roce 1961, ovšem Stalin z letenské pláně nezmizel ani po opakovaném použití dynamitu (demolice byla téměř stejně náročným projektem jako výstavba); visel nad ní dál jako neviditelný př́zrak. Ne náhodou se po roce 1989 objevilo hned několik projektů na zaplnění tohoto místa, nabitého symbolickou mocí. V roce 1991 zde tak byl postaven obrovitý metronom; podle Hojdy s Pokorným se jeho instalace rovná „rituálnímu odkletíc, symbolizujíce „opětovné spuštění zastavených dějin“" (Hojda a Pokorný 1996: 221). ${ }^{23}$

Obdobný „minusový efekt“ se projevuje po přejmenování názvů ulic, náměstí či celých měst. Při každé společenské změně bývají vedle pomníků (a vzhledem k technologické nená- 
ročnosti často ještě před nimi) obvykle první na řadě jména ulic a náměstí. Dějiny pojmenování ulic a náměstí se tak podle Macury „stávají paradoxním seizmografem dějinných zvratư“ (Macura 1993: 67). ${ }^{24}$ Jsou známy prípady, kdy štítková a cedulková deratizace k vyčištění daného místa od nežádoucích konotací nestačí; starý název lidé ještě dlouho poté drží v paměti či v neformálních situacích př́mo používají. „Zrušené jméno“, píše Macura, „nebývá přitom vždy zrušeno úplně, často přežívá jako neoficiální synonymum jména oficiálního, připraveno se po letech znovu připomenout a zoficializovat“" (Macura 1997: 68). Klasickým prríkladem tohoto druhu je pražské Wilsonovo nádraží („ubránivši““ se v povědomí veřejnosti oficiálnímu přejmenování na „Hlavní“), či naopak, brněnské náměstí Rudé armády, pro něž se mezi staršími generacemi stále užívá hovorová zkratka „Rud'ák“, přsestože náměstí bylo přejmenováno na Moravské. ${ }^{25}$

Také v př́ipadě pomníků není leckdy fyzické odstranění zapotřebí - pokud se podaří úspěšně přehodit výhybku významu, ke kterému odkazuje. V případě Památníku národního osvobození, národního kenotafu v Praze na Vítkově (jenž je sám o sobě symbolickým prostorem, místem vítězství husitů nad první křižáckou výpravou v roce 1420), byla tato výhybka přehozena hned dvakrát. Toto místo bylo původně koncipováno pro pomník Jana Žižky, jehož zadání bylo hotové již na počátku 20. století. Jezdecká socha husitského polního vůdce však byla odhalena až v roce 1950; mezitím sloužil objekt, na němž byla socha postavena, jako oficiální mauzoleum padlých legionářů a ostatních „bojovníků za naši samostatnost“. Po Únoru 1948 ovšem vznikl problém, jak s památníkem naložit. „Nový svět socialismu potřeboval sakrální místo typu mauzolea“, píše V. Macura (1993: 53), k čemuž byl objekt jako takový vhodný; stačilo tedy, $\mathrm{v}$ intencích celkové proměny oficiálních znaků národní identity, změnit jeho určení. „Mauzoleum bylo postupně z mauzolea legionářského přetvořeno v mauzoleum ,velkých synů dělnické tř́́dy . Po uložení balzamovaného těla Klementa Gottwalda se vítkovský monument stal dokonce př́mo dvojníkem Leninova a Stalinova mauzolea v Moskvě“ (Macura 1993: 54). ${ }^{26}$ Významovou konverzí prošel památník podruhé po roce 1990, kdy byly ostatky pohřbených soudruhů vyzvednuty a uloženy na Olšanském hřbitově (jinak dalším posvátném národním místě), zatímco národní památník byl vysvěcen biskupem Lebedou (Hojda a Pokorný 1996: 162), kterýžto akt symbolicky stvrdil jak změnu oficiální orientace národní identity, tak výměnu mocenského aparátu, který o jejím výkladu rozhoduje. A proměna pokračuje - v roce 1998 bylo založeno „Občanské sdružení Vítkov pro zřízení expozice totalitních režimů a české státnosti“, jehož záměrem je „rehabilitace Národního památníku, oživení vrchu Vítkova a zejména zprostředkování společné historie i př́tomnosti pro vytváření nové budoucnosti“, a to formou zřízení Expozice české státnosti i „výstavního, kulturního a dokumentačního centra totalitních režimů v celosvětovém měřítku“ (viz http: // www.vitkov.net). ${ }^{27}$

\section{Závěrem: co s nimi?}

Spletité dějiny národních symbolů, jež zde byly na několika př́ikladech českých pomníkových a etno-krajinných horeček ilustrovány, dokládají, že snaha zamést určité méně atraktivní etapy a kapitoly národní historie pod koberec (do skladu, na půdu, na šrotiště) se potkává s pozoruhodně houževnatým odporem, skrytým ani ne tak ve vědomé revoltě (části) národa proti 
oficiálním reinterpretacím a novým identitifikačním modelům, jako spíše v síle samotných symbolů, jejichž významy mají mnohem tužší kořínek než materiální reprezentace. Možná i s tímto vědomím se rozhodli radní města Litomyšle $\mathrm{k}$ ojedinělému kroku - nevymístovat po roce 1989 sochu Zdeňka Nejedlého od tamní I. základní školy, ale připojit k ní desku s nápisem „Zdeněk Nejedlý 1878-1962. Rozmnožil i poškodil kulturu českou, přinesl poctu i úhonu rodnému městu, jež oceňuje dobré, zavrhuje špatné jeho skutky. “28 Politicko-historický kompromis? Alibismus? Kýč? Prozíravost? Možná od každého trochu. ${ }^{29}$ Každopádně však originální př́spěvek do diskuse o tom, zda by sochy, pomníky, kenotafy a další reprezentace národní (či jiné) identity a historických mytologií namísto jejich pracného a často marného mýcení neměly raději zůstávat lidem na očích - at' už jako memento mori, anebo jako výraz pokory před dějinami, jež mají tendenci se opakovat. Diagnózu Petra Pitharta, že Češi jsou nemocní svými dějinami (Pithart 1990: 255-256), je možné doplnit o hypotézu, že jednou z prŕčín této choroby je ustavičné vytlačování určitých událostí ze sféry viditelných reprezentací do kolektivního nevědomí. Otázkou je, zda by nebylo lépe se s nimi smíriit - i za cenu toho, že národní historie pozbude něco na svém lesku a integritě - než je uzamykat do lapidárií a pritom se neuroticky obávat jejich návratu.

V dějinách totiž definitivně nikdy uklidit nelze, říkají Hojda s Pokorným (1996: 20), jakkoli se o to lidé neustále pokoušejí. Vždy se totiž najdou nějaké průduchy, kterými prosakují na povrch události a souvislosti, které měly být navždy vymístěny a vymazány z kolektivní paměti. A přestože se leckdy může zdát, že virus společenské amnézie již nenávratně poškodil všechna záznamová média nesoucí informace o jistých součástech minulosti národa (a že tedy, řečeno s Kunderou, „,šechno bude zapomenuto“), existuje naděje, že se v nějaké zapomenuté skřŕni, v muzejním sklepení či pavučinami opředeném archívu podaří objevit ztracené prvky národní semiosféry, podněcující k problematizaci zavedených národních mýtů a stereotypů a ke kritickému uvažování o národní identitě.

\section{Poznámky}

1 Tento text vznikl na základě autorovy diplomové práce „Symbolická prezentace národní identity“, obhájené na Katedře sociologie FSS MU v červnu 2000.

2 Angelika Bammer (1994: xi) popisuje displacement jako „oddělení lidí od jejich původní kultury skrze fyzickou dislokaci (jako uprchlíci, imigranti, migranti, exulanti nebo vyhoštěnci) nebo kolonizující vnucení cizí kultury“. Tento esej se vztahuje především ke druhé polovině definice, odkazující k vymístění na symbolické rovině. Vymezuje se ovšem současně (v konstruktivistickém duchu) vůči chápání národní kultury a identity jako „autentické“, statické či esenciální entity, jak by snad uvedený citát mohl naznačovat.

3 V sociologické teorii se analogicky rozlišuje vědomí kolektivní př́íslušnosti jako „in-group“ vs. „out-group“, zavedené Williamem G. Sumnerem.

4 Indentifikátory chápe Střítecký jako vnější znaky, skrze něž se identifikace uskutečňuje a které, jakkoli navzájem často velice heterogenní, tvoří komplexní „obrazy identifikace“. Roli identifikátorů mohou hrát libovolné předměty a patří mezi ně „kritéria jako etnikum, řeč, stát, písmo, náboženství; př́rodní útvary, události, věci, osoby, zvířata, svatí anebo dokonce věci, které vůbec neexistuji““ (Stř́itecký 1994: 55). 
Jak píše Anthony D. Smith, „...v mnoha ohledech jsou národní symboly, zvyky a ceremonie tím nejsilnějším a nejtrvanlivějším aspektem nacionalismu“ (Smith 1991: 77). Jednotlivé koncepty, které nacionalismus používá a skrze něž se zviditelňuje - autonomie, identita, duch národa, autenticita, jednota a bratrství -, formují vzájemně provázaný jazyk či diskurz, který má své expresivní ceremoniály a symboly. Tyto symboly a ceremonie jsou podle Smitha „tak silně zakořeněny do světa, který obýváme, že je z převážné části bereme jako dané. Obsahují viditelné atributy národa - vlajky, hymny, přehlídky, národní měnu, hlavní města, př́sahy, lidové kroje, folklórní muzea, válečné pomníky, oslavy národních padlých, pasy, hranice - stejně jako skryté aspekty, jako ,národní rekreační střediska, venkov, lidové hrdiny a hrdinky, pohádky, pravidla chování, architektonické styly, umění a řemesla, způsoby plánování měst, zákony, způsoby výuky, praktiky a vojenské kódy - všechny tyto distinktivní zvyky, mravy, styly a způsoby jednání a cítění, které jsou sdíleny členy komunity dané historické kultury“ (Smith 1991: 77). Tyto symbolické prvky ztělesňují základní myšlenky nacionalismu, zviditelňují je a zosobňují pro každého jedince; je to „,abstraktní ideologie v hmatatelných, konkrétních termínech, které vyvolávají okamžitou emocionální odpověd' všech členů komunity“ (Smith 1991: 77). V podobném duchu analyzuje tento „banální nacionalismus“, který je natolik pevnou součástí každodennosti, že nám promlouvá přímo do podvědomí, také Michael Billig (1995).

6 „Semiosféra“ je termínem ruského lingivisty Jurije M. Lotmana, který jej používá ve své koncepci kulturního transferu a kulturního rozvoje. Podle Vladimíra Macury tento termín funguje jako „opačný pól výchozího, až př́liš atomárního pojmu, jakým je znak“ (Macura 1993: 5). Základním konstitutivním prvkem semiosféry je podle Macury jazyk.

7 Anthony Smith definuje „ethnoscapes“ jako „poetické krajiny“, jako „krajiny obdařené poetickým etnickým významem prostřednictvím historizace př́rody a teritorializace etnických vzpomínek“ (Smith 1999: 16). Mohou se krýt s celým územím, na něž si určité etnikum činí nárok (,země česká, domov můj“; Izrael - země zaslíbená), anebo s jeho jednotlivými, více či méně kompaktními geografickými součástmi (údolí Rýna, Seiny či Vltavy; Český ráj; Tatry; norské fjordy; holandské hráze a kanály atd.).

8 Je to možné proto, že, jak podotýká Z. Mach, ,jen málo lidí se stará o detailní popis a chronologii“", o to ,jak se věci udály. [...] Pro většinu lidí existuje kombinace dávných hrdinů a událostí, která je z pohledu vědecké logiky chaotická, ale přesto formuje koherentní image národa, etnické skupiny nebo komunity, jeho slávy a vítězství, jeho utrpení a utlačovatele, jeho historického poslání a jeho práv ve vztahu k jiným skupinám. Výsledek takové mytické znalosti minulosti je image sociálního univerza, které je smysluplné a integrální a které organizuje lidské myšleni““ (Mach 1989: 60).

Žádný, byt' sebetotalitárnější režim v dějinách nebyl nikdy schopen totální kontroly semiosféry - takové, jakou popisuje ve svém románu 1984 George Orwell.

10 Princip symbolického vymístování tak nese citelnou podobnost s principem diferänce, který podle J. Derridy znamená, že „každý pojem je de iure a bytostně vepsán do řetězce či systému, v jejichž rámci odkazuje systematickou hrou diferencí mimo sebe k jiným pojmům systému“ (Blecha 2000: 282).

„Od samého počátku představuje téměř každý pomník určitý politický čin. Své politické souvislosti ovšem zdaleka nemá jen zadání pomníku a způsob jeho provedení. Odhalení pomníku dává př́ležitost $\mathrm{k}$ otevřené i skryté manifestaci politických postojů při proslovech; žurnalisté se mohou zabývat počítáním účastníků slavnosti a podle toho usuzovat na momentální popularitu nejen toho, k jehož poctě byl pomník vztyčen, nýbrž i těch, kteří se jím zaštit’ují. U pomníků se konají manifestace, směřují k nim průvody, kladou se věnce, proti pomníkům se demonstruje. Pomníky jsou proto také symbolickými i skutečnými epicentry vlivu, který je určitá komunita [...] schopna na daném teritoriu prosadit“ (Hojda a Pokorný 1996: 18).

12 Tato akce nezůstala zdaleka osamocena: stržení staroměstského sloupu se stalo určitým precedentem, jenž odstartoval celou vlnu ničení mariánských a nepomucenských soch na českém venkově 
(např́iklad v Dobrovici, ve Slaném) i v Praze.

13 Ferdinand Peroutka: Vandalství na pokračování. Http://mariansky-sloup.wz.cz/clanky.htm, odkaz platný k 30. 11. 2004.

14 Obnova mariánského sloupu naráží také na nesouhlas protestantských církví, jež v tomto aktu spatřují symbolické připomenutí rekatolizace českého národa po bitvě na Bílé Hoře (Štráfeldová 2003). Jakkoli Magistrát hlavního města Prahy ještě o znovuobnovení pomníku nerozhodl, jeho rekonstrukce postupně pokračuje; od 3. 11. 2003, tedy 85 let od stržení sloupu, stojí ve výklenku u jižního bočního vchodu do Týnského chrámu replika sochy Panny Marie, sestavená z úlomků původní sochy a vysvěcená kardinálem Vlkem (tamtéž).

15 V souvislosti s erupcí protihabsburských vášní, doprovázejících okamžiky po vzniku republiky, stojí za to připomenout, že Český svaz - společný orgán českých poslanců na ř́ššé radě - v koordinaci s Národním výborem ještě v roce 1917 přijal usnesení reagující na průběh světové války, ve kterém vyhlásil svou jednoznačnou loajalitu panovnickému domu a odmítal „vměšováni““ mocností Dohody do státoprávních záležitostí Rakouska-Uherska.

16 Jezdecká socha Františka I. stála jako dominanta velkého pomníku a zároveň kašny na nově vybudovaném nábřeží mezi Křižovnickým náměstím a dnešní Národní třídou. Už v čase velkých politických nepokojů v roce 1893 se stala terčem symbolické agrese: na krk císaře kdosi navlékl oprátku. Vymístění symbolu habsburské nadvlády bylo dokonáno v roce 1919: pomník zůstal, ale socha z něj byla vystěhována, což časopis Světozor komentoval popiskem k fotografii následovně: „Praha bez Habsburků a jejich pomahačů. Konečně Praha nabývá vzhledu ryze národního, českého, kdy poslední pomníky našeho otroctví jsou odstraněny!“ (Hojda a Pokorný 1996: 39.)

17 Socha Marie Terezie v Bratislavě byla svržena v roce 1921, aby uvolnila místo M. R. Štefánikovi, kterýžto poté ,př̌ežil“ Slovenský štát (nacistickým důstojníkům údajně pomník věnovaný pilotovi nijak nevadil), nikoli však nástup komunismu - socha byla rožřzána roku 1952 (Hojda a Pokorný 1996: 176-182).

18 Památka na císaře Josefa II. byla v českém prostředí tradičně rozporuplná - zatímco český venkov v něm viděl osvoboditele od nevolnictví, pro představitele buržoazie a národního hnutí byl symbolem centralizačních a germanizačních sil (viz Hroch 1999). Jazýčkem na vahách interpretace významu Josefa II. byla masová a okázalá obliba Josefa II. u Němců, která způsobila, že se tento panovník Čechům definitivně znechutil a po vzniku republiky neváhali s jeho symbolickou likvidací. Odstraňování soch v německém pohraničí, které organizovali zejména legionáři - s evidentním cílem dosáhnout symbolického ovládnutí stále ještě „odbojných“ periferií mladé republiky - se však neobešlo bez konfliktů s místním obyvatelstvem, jako tomu bylo koncem listopadu 1920 v Teplicích (německá strana prý tehdy hovořila o „pomníkovém teroru“). Odstranění tamější sochy mělo za následek bourání dalších Josefư: v Chebu, Aši, České Lípě či Děčíně. Kuriózním a paradoxním „koncem pomníků Josefa II. v Čechách“ bylo přivtělení Sudet k Říši, kdy byly všechny dochované exponáty odevzdány na oltáŕ vlasti v rámci sběru kovů (Hojda a Pokorný 1996: 142).

19 Jak Pithart připomíná, ,po Radeckém zbylo jen kuriózní, ale přesto živé úsloví ,To si pleteš s Radeckým', což je hovorová reakce na nějakou mýlku v řeči partnera. Je to snad bezděčná připomínka zmatku, který charakterizuje českou mysl v jejím vztahu k vybíleným - uklizeným - místům v české historii?““ (Pithart 1990: 260). Potřebné „odkouzleni““ prostranství, poskvrněného dlouholetou přítomností nežádoucího symbolu, zabezpečila instalace mohutné sedící sochy francouzského historika a bohemofila Ernsta Denise (1928), ovšem pouze na dvanáct let, než jej odstranili nacisté.

Mozartova socha nakonec přece jen vystavena byla - skončila v roce $1920 \mathrm{v}$ Teplicích, kde (což je také paradoxní a př́żnačné zároveň) před místní radnicí vystřídala Josefa II., „zosobňujícího němectví“ (Hojda a Pokorný 1996: 127-133).

Socha byla součástí rozsáhlého výpravného sochařského komplexu, jenž ve dvacátých letech vybu- 
doval nedaleko Rudky u Blanska amatérský sochař Stanislav Rolínek, který do skalního pískovce vytesal legendární postavy blanických rytířu. Jak píše V. Macura, „měl to být skutečný Blaník, Blaník otevřený, didaktický“ (Macura 1993: 50). „Jeskyně blanických rytírưu“ se ale neomezila jen na postavy rytî́r̊ a sv. Václava (v nadživotní velikosti) jako jejich mytického vůdce: Rolínek k nim přitesal ještě postavy československých legionářů vedených T. G. Masarykem. „Bájný vůdce národa $\mathrm{v}$ jeskyni, v temnotách ( $\mathrm{v}$ ř́rši mytického bezčasí) a současný vůdce národa, prezident Osvoboditel, umístěný venku, v plném světle, v ,našem čase‘, vytvořili dvojici“", komentuje Macura tento výjev (1993: 50-51).

Nejpozoruhodněji se s jeho pomníkem vypořádali v Plzni v rámci jakési „antidemonstrace“, která měla zastínit měnovou reformu a dělnické bouře, které po ní následovaly: Masarykovi byla na krk hozena oprátka, socha stržena a sešrotována a „na místě sochy byl vyhlouben bazén, aby se bývalý pomník nepřipomínal ani v terénu - důslednost, o jaké se dřívějším bořitelům pomníkủ ani nesnilo“ (Hojda a Pokorný 1996: 202). Svržení sochy nejvyššího symbolického představitele čerstvě svrženého režimu se zdá být univerzálně praktikovaným rituálem „,přechodu“ z jednoho typu politického řádu k jinému, jak dokazují již pomalu blednoucí novinové fotografie padlých Leninů, připomínající pád komunismu v zemích střední a východní Evropy, ale i pompézní a globálně cirkulující televizní záběry stržení sochy Saddáma Husajna po dobytí Bagdádu vojsky USA v březnu 2003 (jakkoli spontaneitu tohoto aktu poněkud snižuje skutečnost, že tím, kdo sochu z podstavce svrhl, byl americký tank).

Stalinův stín ovšem leží nad Letnou i nadále: když nechala Občanská demokratická strana v průběhu předvolební kampaně k parlamentním volbám v roce 1998 instalovat na Letenské pláni olbřímí billboard s portrétem Václava Klause, vyvolalo to téměř automaticky vlnu satirických i zcela vážně míněných asociací na kníratého muže, který vykonával symbolický dohled nad Pražany v letech 1955-1961.

Bohatství těchto zvratů v moderních českých dějinách dokládá fakt, že některé české ulice změnily během posledního století svi̊j název osmkrát (Lipold 1999).

Někdy ovšem, připomíná Macura, ,přežívá alespoň zčásti zvuková a grafická podoba jména a tvůrci té kosmetické úpravy, garanti nového ideového souladu jména s řádem, se spokojí jen s proměnou významovou. Ulice zasvěcená Naděždě Krupské v Teplicích v Čechách se jen nenápadným zásahem pozměnila v ulici Krupskou, jako by se název odjakživa týkal nedaleké obce Krupka. Z ulice 7. listopadu v Praze se zčistajasna stala ulice Listopadová, v této podobě docela prrijatelná i nyní. Z ulice Generála Svobody v Mikulově máme dnes ulici Svobody. Bylo dosaženo groteskního kompromisu mezi zvykem a potřebou změny“ (Macura 1993: 68). V Brně je možno najít celkem třináct ulic, které po roce 1989 neprodělaly změnu názvu, nýbrž „pouze“ dedikace, což je řešení jistě nejefektivnější; místní radnice tak ušetřily peníze za předělávání cedulí i map a uchránily své obyvatele před orientačními zmatky. Např́iklad ulice Koutného v Lišni byla pojmenována v roce 1978 podle Tomáše Koutného, zakládajícího člena KSČ; po roce 1989 byla dedikace přenesena na dr. Josefa Koutného, profesora teologie a obět' komunistických represálií. Podobně Konečného náměstí (původně „Am Tivoli“), v roce 1925 dedikované dr. Aloisi Konečnému, zasloužilému učiteli a senátorovi, bylo od roku 1974 vzpomínáno v souvislosti se jménem Hynka Konečného, zasloužilého funkcionáře KSČ; v současnosti opět nese jméno zasloužilého senátora. Ulice Pionýrská je po roce 1989 „věnována průkopníkům nových myšlenek a činů v rámci rozvoje společnosti“ (Flodrová a kol. 1984, Zř́́dkaveselý 1996).

26 Byly zde umístěny symbolické hroby Fučíka a Švermy, sem byl pohřben Bohumír Šmeral, Josef Haken, Gustav Kliment, Václav Nosek, Bohuslav Vrbenský, z literátů S. K. Neumann, Ivan Olbracht, Marie Majerová (Macura 1993).

27 Proměna určení pomníkového areálu se po roce 1989 odehrála také v př́padě památníku ostravské operace v Hrabyni, který byl přeměněn na Muzeum člověka a války (Hojda a Pokorný 1997: 223). 
28 Tato slova citují ve své publikaci také Hojda s Pokorným (1997: 224), nicméně, jak upozorňuje Martin Boštík (2004: 41), nápis samotný začíná citátem Blaise Pascala „Odmítám ty, kdož se rozhodli pro oslavu člověka, stejně jako ty, kdož se rozhodli jej tupit..., mohu dát za pravdu jen těm, kdož v úzkostech hledají.“ Autorem celého nápisu je litomyšlský historik Milan Skřrivánek.

29 Historie pomníku Zdeňku Nejedlému v Litomyšli není nicméně umístěním „vysvětlujícící“ tabulky u konce. Fakt, že se pomník ani po více než deseti letech od tohoto symbolického očištění nestal „zapomníkem“, mrtvým totemem, dosvědčuje aktuální iniciativa za odstranění pomníku, vedená především členy sdružení politických vězňủ, žijícími na litomyšlsku (k roli Zdeňka Nejedlého v politických procesech v tomto regionu viz Boštík 2004).

\section{Literatura}

Anderson, B. 1991. Imagined Communities. Reflections on the Origin and Spread of Nationalism. London, New York: Verso.

Bammer, A. 1994. „Introduction.“ In A. Bammer (ed.) Displacement, Bloomington: Indiana University Press.

Billig, M. 1995. Banal Nationalism. London: SAGE.

Blecha, I. 2000. Filosofická čítanka. Nakladatelství Olomouc.

Boštík, M. 2004. Monstrproces „,Střiteský a spol.“, Litomyšl 1950. Historická studie o síle a slabosti poválečného člověka. Regionální muzeum v Litomyšli.

Cerulo, K. A.1995. Identity Desings. The Sight and Sounds of a Nation. New Brunswick, New Persey: Rutgers University Press.

Flodrová, M. a kol. 1984. Seznam ulic města Brna s vývojem jejich pojmenování. Brno: Muzejní a vlastivědná společnost.

Havelka, M. 2001. Dějiny a smysl. Obsahy, akcenty a posuny „české otázky“ 1895-1989. Praha: Nakladatelství Lidové noviny.

Hojda, Z., Pokorný, J. 1996. Pomniky a zapomniky. Praha, Litomyšl: Paseka.

Holý, L. 2001. Malý český člověk a skvělý český národ. Praha: SLON.

Hroch, M. 1999. V národním zájmu. Praha: Nakladatelství Lidové noviny.

Jenkins, R. 1996. Social Identity. London, New York: Routledge.

Lipold, J. 1999. „Ulice nesmějí nést jména živých.“ MF DNES, 2. 12.: 3.

Loewenstein, B. 1997. My a ti druzí. Dějiny, psychologie, antropologie. Brno: Doplněk.

Mach, Z. 1989. Symbols, Conflict and Identity. Krakow: Uniwersytet Jagiellońskiego.

Macura, V. 1993. Masarykovy boty a jiné semi(o)fejetony. Praha: Pražská imaginace.

Morley, D., Robins, K. 1995. Spaces of Identity. Global Media, Electronic Landscapes and Cultural Boundaries. London, New York: Routledge.

Pechar, J. 1995. Být sám sebou. Pojem identity a jeho meze. Praha: Hynek.

Pithart, P. 1990. Déjiny a politika. Eseje a úvahy z let 1977-1989. Praha: Prostor.

Smith, A. D.1991. National Identity. London: Penguin Books.

Smith, A. D.1999. Myths and Memories of the Nation. Oxford: Oxford University Press.

Střítecký, J. 1994. „Identitäten, Identifikationen, Identifikatoren.“ In E. Schmidt-Hartmann (ed.) Formen des nationalen Bewußtseins im Lichte zeitgenössischer Nationalismustheorien. Vorträge der Tagung des Collegium Carolinum in Bad Wiessee vom 31. Oktober bis 3. November 1991. München: R.Oldenbourt Verlag. 
Štětka, V. 2000. Symbolická prezentace národní identity. Magisterská diplomová práce, Fakulta sociálních studií Masarykovy univerzity, Brno.

Štráfeldová, M. „Vrátí se na Staroměstské náměstí mariánský sloup?“ Př́íspěvek ve vysílání Českého rozhlasu 7 - Radia Praha 4. 11. 2003. Dostupné z: http://design.radio.cz/cz/ clanek/47031/limit

Zřídkaveselý, F. 1996. Nové a změněné názvy ulic v městě Brně 1984-1996. Doplněk ke knize M. Flodrové, B. Galasovské a J. Vodičky Seznam ulic města Brna s vývojem jejich pojmenování. Muzejní a vlastivědná společnost v Brně.

Internetové zdroje

http://mariansky-sloup.wz.cz/clanky.htm

http://www.vitkov.net

\section{Autor}

Mgr. Václav Štětka (1976) vystudoval sociologii a historii na FF a FSS MU v Brně, na bakalářském stupni také obor mediální studia a žurnalistika. V současnosti je šéfredaktorem univerzitního měsíčníku Muni.cz a externím doktorandem na Katedře mediálních studií a žurnalistiky FSS MU. Zabývá se problematikou mediální reprezentace nacionalismu a národní identity ve věku globalizace, což je také tématem jeho disertační práce. Kontaktní e-mail: stetka@fss.muni.cz 